\title{
Power supply of trams in Poland - current state and perspectives of development
}

\author{
Adam Szeląg ${ }^{1, *}$, and Tadeusz Maciołek ${ }^{1}$ \\ ${ }^{1}$ Warsaw University of Technology, Institute of Electrical Power Engineering, Electric Traction Division, \\ ul. Koszykowa 75, 00-662, Warsaw, Poland
}

\begin{abstract}
Sustainable development of agglomerations requires efficient and ecological transport systems, i.e. electrified transport. In order to achieve the required results of operation of electrified urban transport, especially energy efficiency, it is required to closely examine the existing power supply systems. The biggest share of urban traction systems in Poland belongs to tram systems (in 15 agglomerations and cities). Recent years have witnessed an increased interest in modernisation of the existing lines and construction of new ones. Enhancement of RAMS (Reliability, Availability, Maintainability, and Safety) and energy efficiency of supply systems is a necessary requirement, due to fact that new, modern tram rolling stock with higher power poses significant challenge for the existing, in many systems, old power supply infrastructure. Furthermore, due to low driving-range of autonomous vehicles equipped with batteries and a need of frequent charging of storage devices, catenary supplied urban transport will dominate in the areas of its use. In addition, it might be helpful in developing hybrid vehicles supplied both from a catenary and from energy storage devices (charged during run under catenary) on sections without catenary. The paper presents parameters characterizing tram power supply systems in Poland. The analyses carried out for many tram lines have shown that even at relatively low investments for modernisation of the tram power supply system, it is possible to obtain fast return (energy saving due to improvement of efficiency of recuperation and the resulting reduction of $\mathrm{CO}_{2}$ emission). Other advantages of modernisations include: enhancement of standards in supply of modern trams with higher power and improvement of reliability due to the reduced risk of disturbances and damages.
\end{abstract}

\section{Introduction}

The interest in electrified rail transport systems has increased considerably in West-European countries at the end of the $20^{\text {th }}$ century $[4,8]$, and in Poland since $21^{\text {th }}$ century. due to significant changes in environment transformed by humans (including high population concentration in cities and suburban areas with simultaneous urban congestion and environmental pollution caused by industry and combustion engine vehicles) This is practically the only effective solution for communication problems in large agglomerations.

The main directions of development of these systems can be described primarily as introduction of new technical solutions for rolling stock, power supply systems and infrastructure, which at the same time fulfil requirements of technical standards, comfort and ensure optimization of both economic and financial indicators $[1,2,3,5,6,7]$.

\section{Tram traction power supply systems in Poland}

Currently in Poland, trams are operated in 15 cities (Warsaw, Łódź together with suburban lines, Silesia conurbation, Cracow, Wroclaw, Poznań, Szczecin, Gdańsk, Bydgoszcz, Toruń, Elbląg, Gorzów Wlkp., Grudziądz, Częstochowa and Olsztyn), and in some cities, trams were eliminated. The total length of tram single track in Poland equals over $1900 \mathrm{~km}$, and it is the second longest network in the EU, after a tram network in Germany, which is almost 2 times longer.

After a long time of stagnation, currently in Poland, one may witness a period of development of tram lines and rolling stock, with a large share of funds coming from urban transport development programmes financed by the EU.

\footnotetext{
* Corresponding author: $\underline{\operatorname{adam} . \operatorname{szelag} @ \text { eee.pw.edu.pl }}$
} 


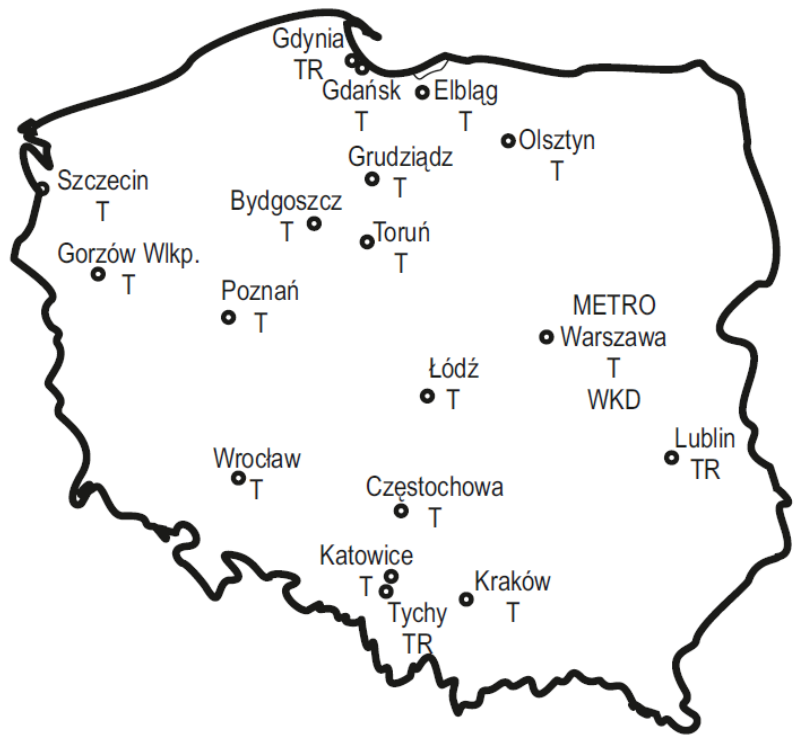

Fig. 1. Urban transport systems in Poland: T-trams, TRtrolleybuses, WKD- Warsaw suburban light rail.

In Warsaw, a new long-term contract for supply of new low-floor trams, including bidirectional ones and units equipped with energy storage devices, is under preparation. Furthermore, intensive works have been carried out in order to modernise various types of already wear-out trams, especially popular $105 \mathrm{~N}$ type trams, by equipping them with choppers, which does not require replacement of motors, or by replacing DC series motors with asynchronous motors supplied by inverters, and by introducing, at least partially, low-floor trams. However, such an approach imposes certain requirements for often outdated electric power infrastructure. In many cases, the selection of a location for a traction substation TS may be limited due to the lack of proper area (especially in city centres) or a distant location of points of connection to a public electrical grid. If substations are located too far one from another, a higher supply voltage may be required (e.g. $1.5 \mathrm{kV}$ DC instead of 600 or $750 \mathrm{~V} \mathrm{DC}$ ). A solution may be to construct a larger number of substations with smaller dimensions and a simplified structure (e.g. container type), which should facilitate selection of a place suitable for a traction substation. In extreme cases one may seek for other solutions, such as: use of a rectifier with a controlled characteristic or leading long feeders with a large cross-section from the existing substation to a traction network at place, where a substation is required to be built. Not without significance is the cost of laying long cables. However, due to lack of accessibility of area in the cities as well as the prices of a land, every effort is made to limit the number of substations to a minimum. Another solution might include constructing an underground substation it is quite typical under metro conditions, but it can be found in other systems as well (this solution has been applied, e.g. for supply of tram networks in the city centre of Poznan); however, such a solution increases the investment costs substantially.

The largest share among the Polish urban carriers using electric traction belongs to tram transport companies. One may observe a noticeable increase in interest in construction of new tram systems (return of trams in Olsztyn) as well as in modernisation of the existing systems. Improvement of reliability, availability and energy efficiency of power supply systems is necessary and of high priority. In recent years one could witness intensified purchase and modernisation of rolling stock thanks to the EU funds.

The structure of a power supply network of urban electrified transport may be very diversified.

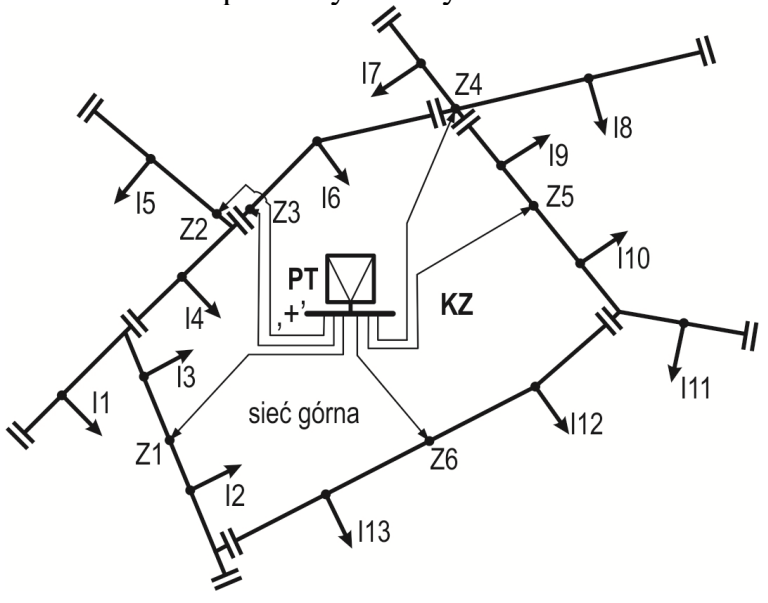

a.)

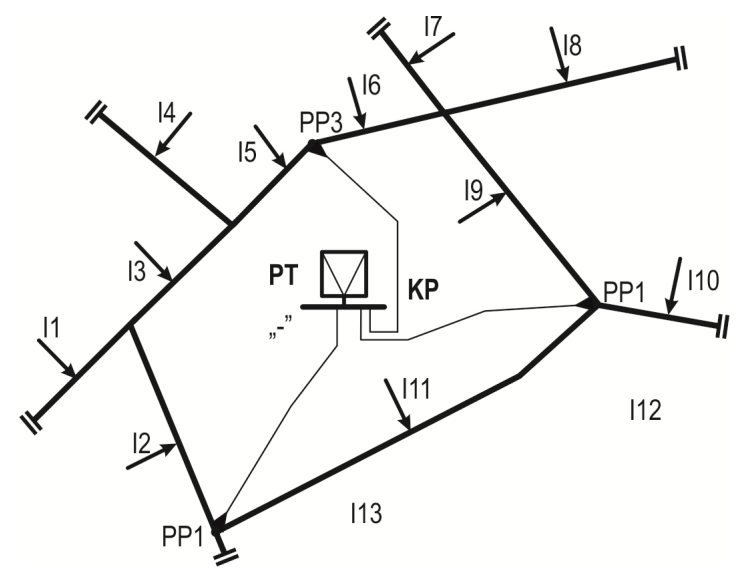

b.)

Fig. 2. A typical centralized scheme of a supply network TS a) supply network, b) return network.

It depends on [6]:

- dimensions of a transport network and power demand during peak hours;

- power and energy transmission from a local electrical grid;

- quality and quantity of energy needed by traction vehicles and auxiliary circuits.

Usually, a power supply network consists of several subsystems providing:

- traction current flow from traction substations to vehicles (supply and return network),

- AC low voltage supply and distribution for auxiliaries and lighting purposes;

- energy distribution of medium voltage lines $(6,15$, 20 or $30 \mathrm{kV}$ ) supplying traction substations as well as auxiliary and non-traction need transformers. 


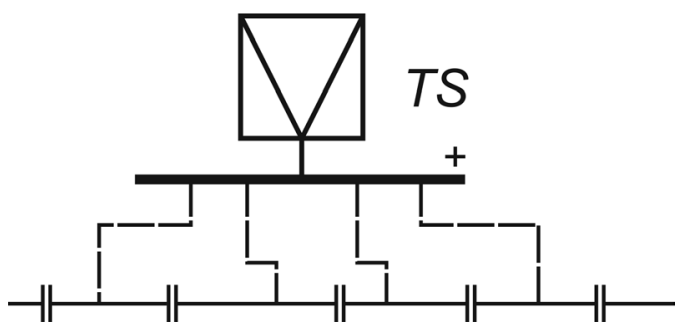

Fig. 3. A linear scheme of a network supplied by a traction substation TS.

There is still some considerable negligence in this area, especially as far as smaller systems are concerned. The upcoming years should change it. Apart from the purchase of rolling stock, it is necessary to make some investments in tram power supply systems. Because the structures of power supply systems were designed many years ago and were based on that time applicable standards. Currently, as outdated from a technical point of view, they are reconstructed and expanded using new technology and solutions.

On the basis of statistical data (obtained from the Polish Chamber of Urban Transport-IGKM) for 13 out of 15 tram systems that exist in Poland, Fig. 4 - 22 (tram systems are numbered from 1 to 13 ) the selected values characterising tram power supply systems are presented. These values area averaged for each tram transport power supply system and they refer to the year 2016. Unfortunately not all data were available from all tram systems, so in some diagrams appears value 0 - lack of data, mostly for a tram system numbered 7).

The values presented in the figures mainly show the structure of a power supply system. When comparing the values, one should take into account the fact that they are represented by average values and they do not reflect a local specific situation that is included in the division of transport into the central parts of cities and suburban areas, where transport service frequency is lower. For high loads in a power supply system a voltage drop in a catenary should be selected as a limitation while assessing operation quality, and for lower loads, a voltage drop in supply and return feeders. Based on statistics simplified in such a manner, it may be quite difficult to assess these power supply systems in terms of quality. In each case, such an assessment would require conducting a study on a power supply system, which should include a thorough analysis of losses and drops of voltage and loads for specific conditions [6]. The qualitative assessments should also include aspects of reliability, availability and impact on the environment and infrastructure.

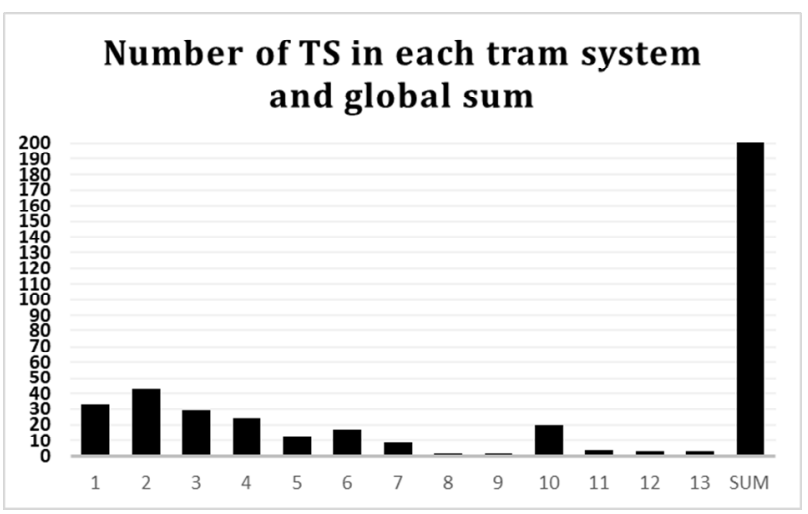

Fig. 4. The number of TSs in 13 tram systems in Poland and a sum of TSs in 13 tram systems, and a global sum.

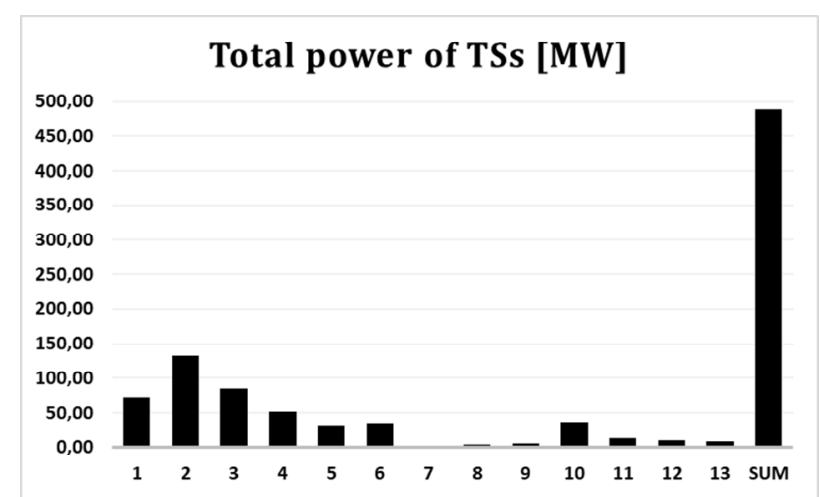

Fig. 5. Power installed in traction substations in 13 tram systems in Poland, and a global sum.

- the number of TSs in each of the 13 systems varies from 2 to 43 (Fig. 4), which gives globally over $200 \mathrm{TSs}$, with most of them being controlled remotely. Power installed in a TS exceeds $500 \mathrm{MW}$ (Fig. 5), the number of rectifier groups used in all 13 tram systems is over 600 (Fig. 6), the average number of rectifier units installed in traction substations varies from 2.7 to 3.9 pieces, while the average number of rectifier groups in one TS is 3 (Fig. 7), and typically one group constitutes a reserve. It gives a spread of power in a range from 135 to $448 \mathrm{~kW}$ per $1 \mathrm{~km}$ of a network (Fig. 8),

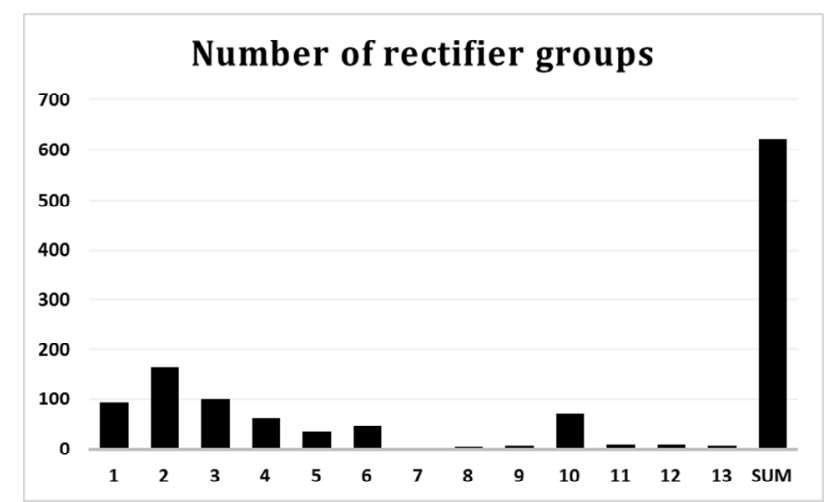

Fig. 6. The number of rectifier groups in a traction substation in 13 tram systems in Poland, a sum of TSs in 13 tram systems, and a global sum. 


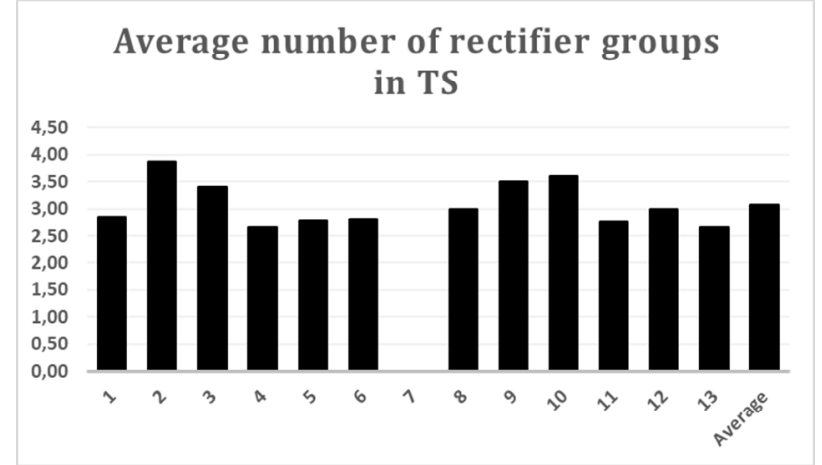

Fig. 7. The average number of rectifier groups in a TS in each of 13 tram systems in Poland and the averaged value for all 13 tram systems.

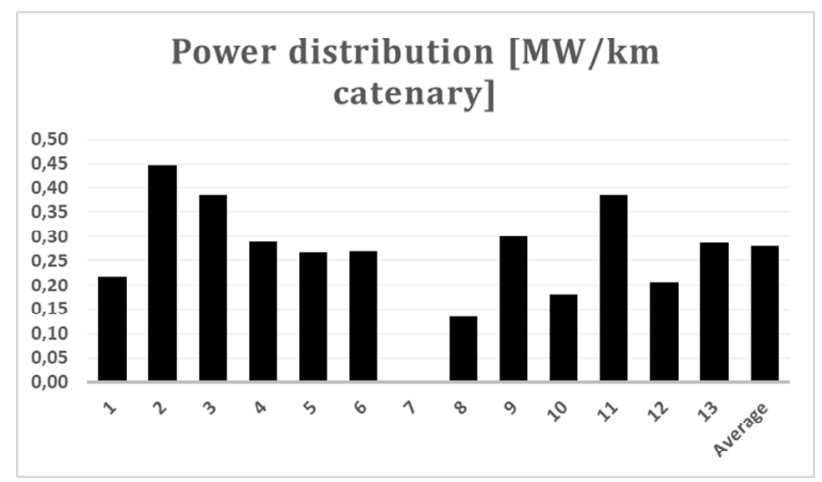

Fig. 8. Average power distribution installed in a TS per $1 \mathrm{~km}$ in each of 13 tram systems in Poland and the averaged value for all 13 tram systems.

Based on the presented data describing tram traction power supply systems in Poland, the following conclusions may be drawn:

- the central power supply system is a typical power supply system for tram traction in large urban agglomerations (Fig. 3), with the sizes of areas and powers of a substation characteristic for such a power supply system (Fig. 5), and large distances of network sections (Fig.9), supply cables (Fig. 10, Fig. 14) and return cables (Fig. 11), and a large number of power supply units (Fig.12) and return cables (Fig.13) per one traction substation.

- the length of feeders per $1 \mathrm{~km}$ of a network is between 0.39 and $1.94 \mathrm{~km}$, and per a substation - from 5 to over $15 \mathrm{~km}$ with a number of power supply units in a substation varying from 4.5 to 10 ;

- length of return feeder cables per $1 \mathrm{~km}$ of a network is in the range from 0.27 to 1.56 , and per a substation from 2.06 to $13.45 \mathrm{~km}$ (Fig. 17), with their number per a substation varying from 3.5 to 9.0 (Fig.13). A lower limit corresponds to a smaller number of installed units and longer sections of a catenary.

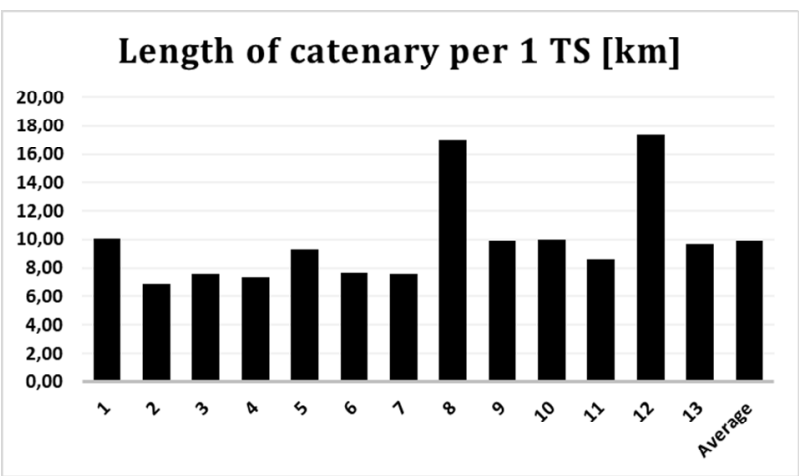

Fig. 9. The average length of a catenary supplied by 1 TS in each of 13 tram systems in Poland and the averaged value for all 13 tram systems.

- the average length of a catenary of a supply area of one substation is in the range between 6.9 and $17.35 \mathrm{~km}$. Longer lengths occur in the cities with a smaller transport volume;

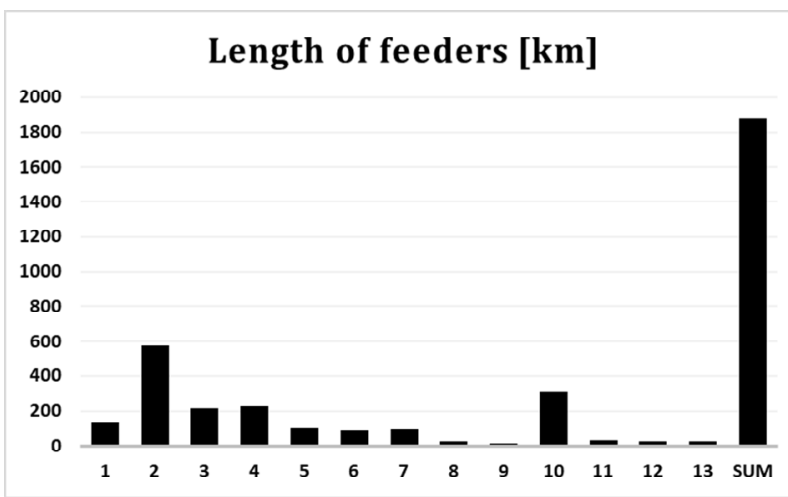

Fig. 10. The length of feeders in 13 tram systems in Poland, a sum of TSs in 13 tram systems, and a global sum.

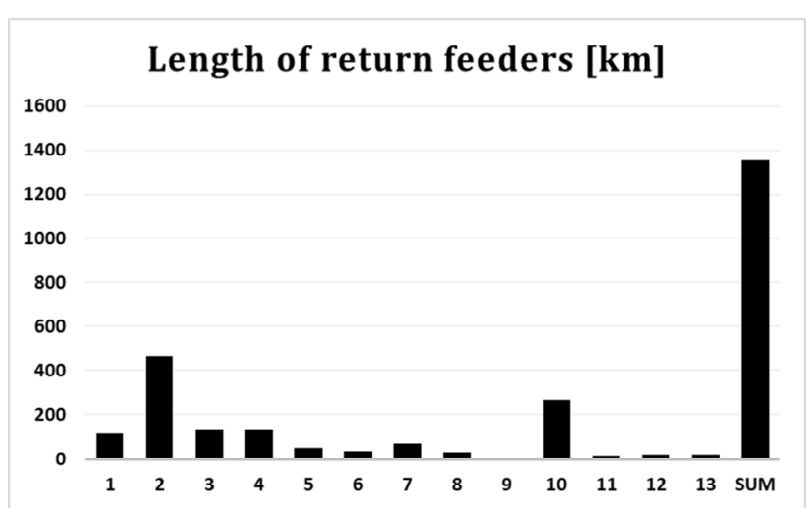

Fig. 11. The length of return feeders in 13 tram systems in Poland, a sum of TSs in 13 tram systems, and a global sum. 


\section{Number of feeders per TS}

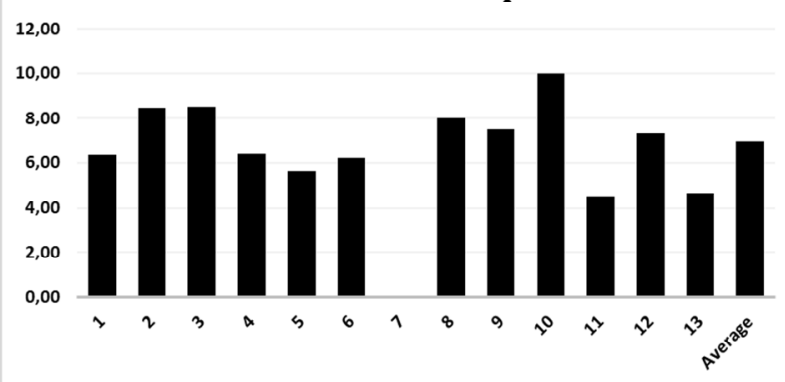

Fig. 12. The average number of feeders in one TS in each of 13 tram systems in Poland and the averaged value for all 13 tram systems.

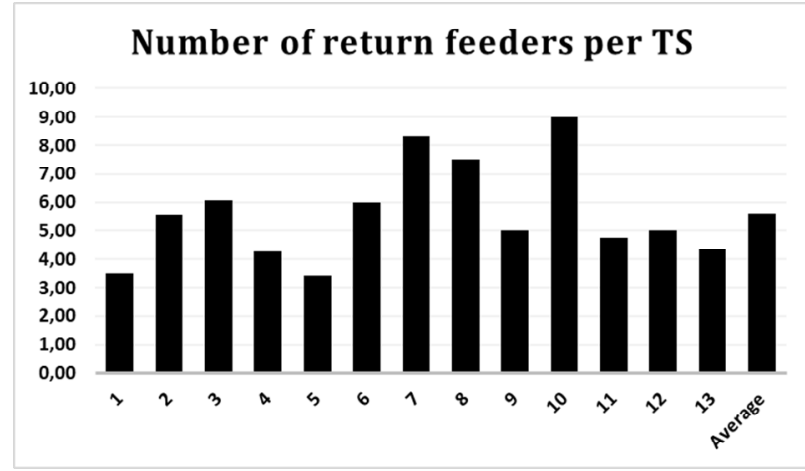

Fig. 13. The average number of return feeders in one TS in each of 13 tram systems in Poland and the averaged value for all 13 tram systems.

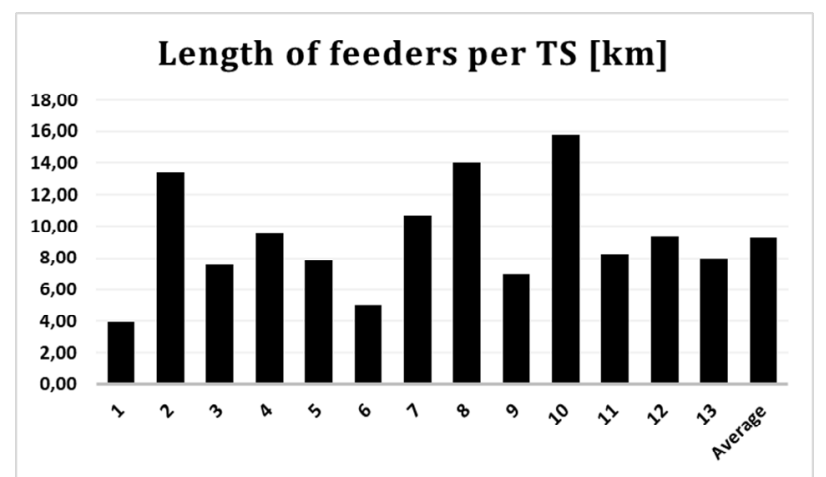

Fig. 14. The length of feeders per 1 TS in 13 tram systems in Poland and the averaged value for all tram systems.

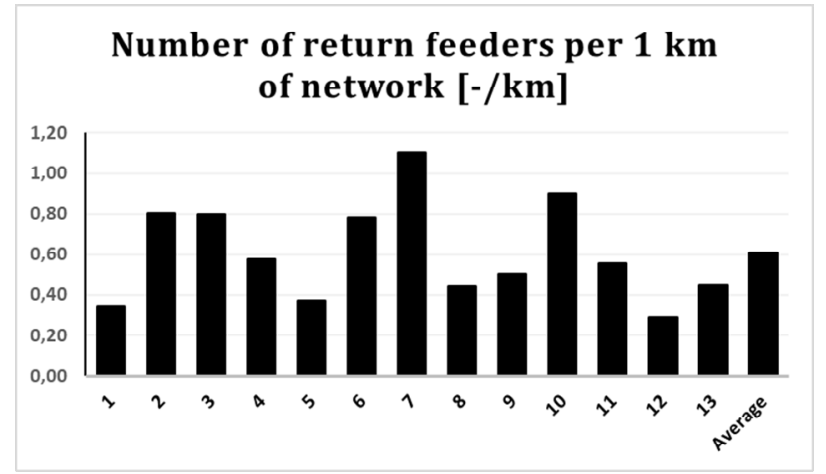

Fig. 15. The number of return feeders per $1 \mathrm{~km}$ of a network in each of 13 tram systems in Poland and the averaged value for all 13 tram systems.
- the number of power supply units per $1 \mathrm{~km}$ of a network is from 0.42 to 1.23 (Fig. 15), which means that a section length of a network supplied by 1 power supply units is between 0.815 and 2.37 (Fig. 16).

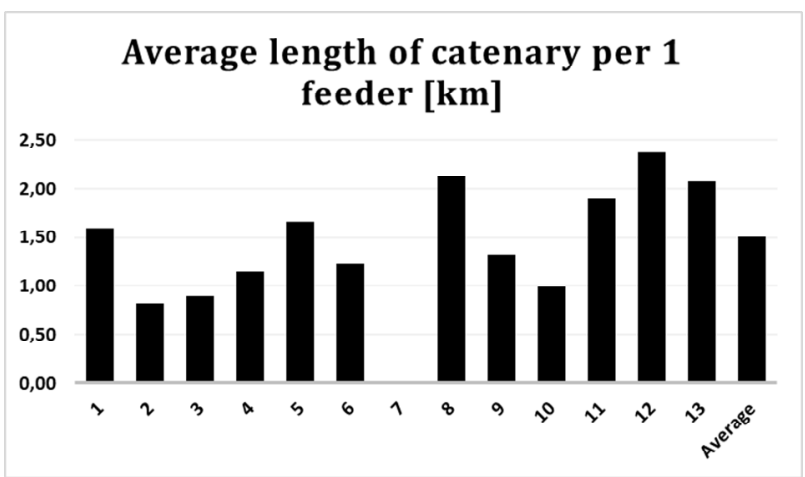

Fig. 16. The average length of a catenary per 1 feeder in each of 13 tram systems in Poland and the averaged value for all 13 tram systems.

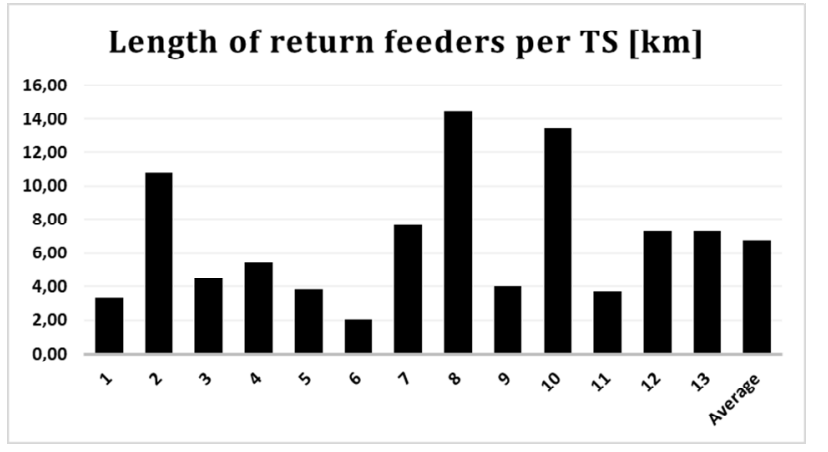

Fig. 17. The length of return feeders per 1 TS in 13 tram systems in Poland and the averaged value for all tram systems.

- longer sections appear in the cities with a lower traffic volume. The average number of return cables per 1 $\mathrm{km}$ is in the range from 0.35 to 0.9 , which means that a catenary length per 1 return cable is from 1.1 to $3.47 \mathrm{~km}$;

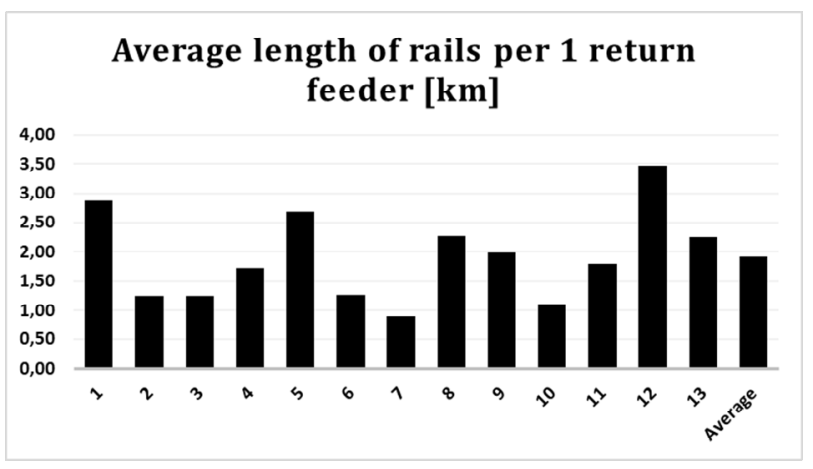

Fig. 18. The average length of rails per 1 feeder in each of 13 tram systems in Poland and the averaged value for all tram systems. 


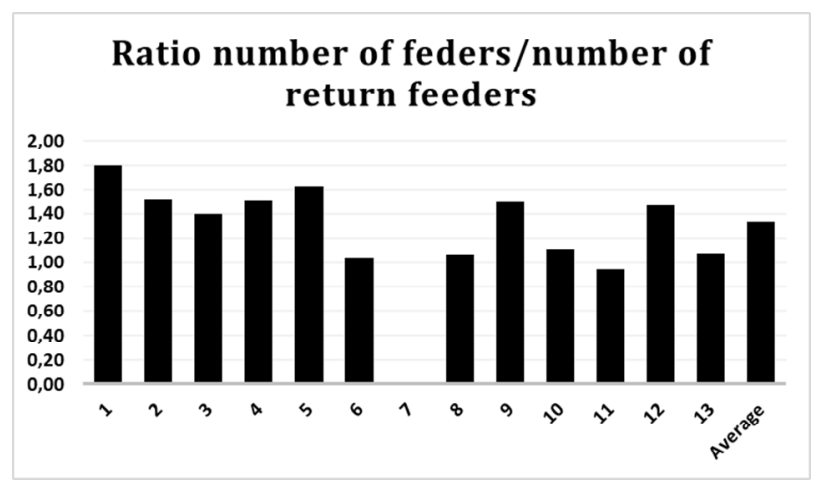

Fig. 19. The ratio of the number of feeders to the number of return feeders in 13 tram systems in Poland and the averaged value for all tram systems.

- only in 1 system there is more return cables than supply cables, while in the remaining the majority belongs to supply cables; the ratio of supply cables to return cables is from 1.04 to 1.8 (Fig. 18);

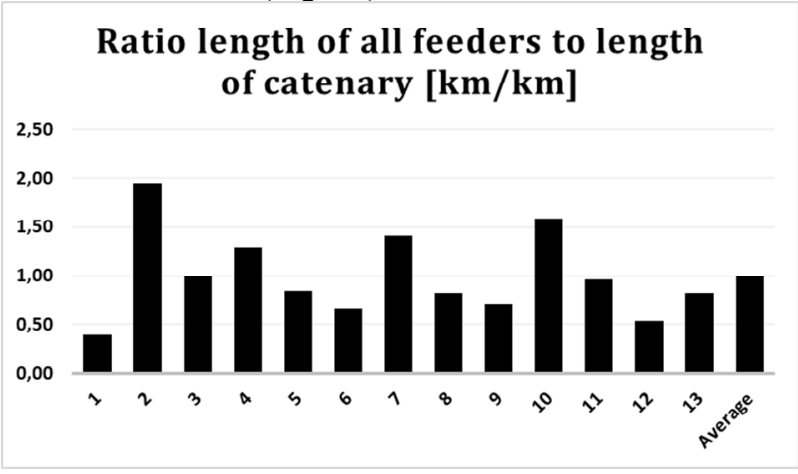

Fig. 20. Ratio of length of all feeders to length of catenary in 13 tram systems in Poland and the averaged value for all tram systems.

- properly selected locations of return points of a rail network for a central power supply system require that the ratio of supply cable lengths to return cable lengths have a value not exceeding 1.4 (half of the systems fulfil this requirement - Fig. 19);

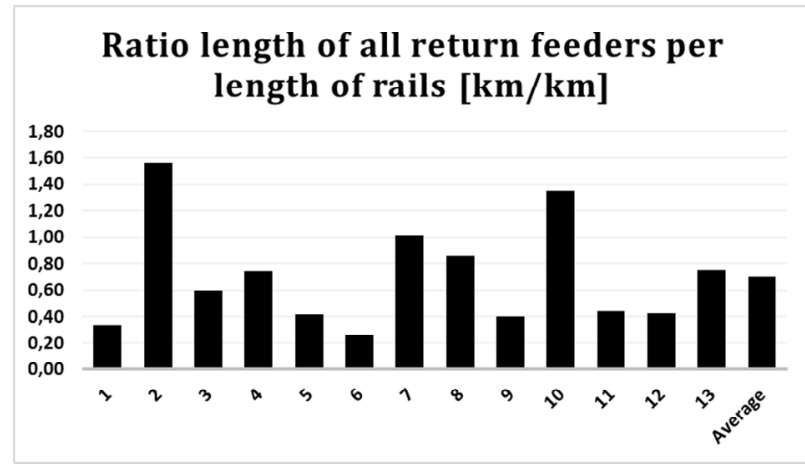

Fig. 21. The length ratio of all return feeders to the length of rails in 13 tram systems in Poland and the averaged value for all tram systems.

\section{Installed power in TS per 1 operating tram [MW]}

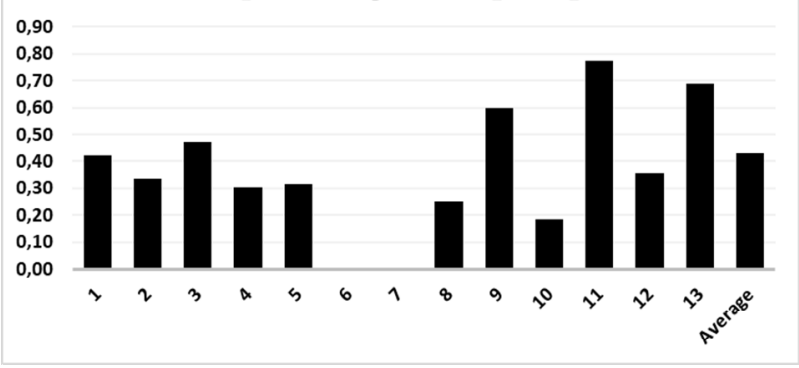

Fig. 22. The average value of installed power in TSs per 1 operating tram in each tram systems in Poland and the averaged value for all tram systems.

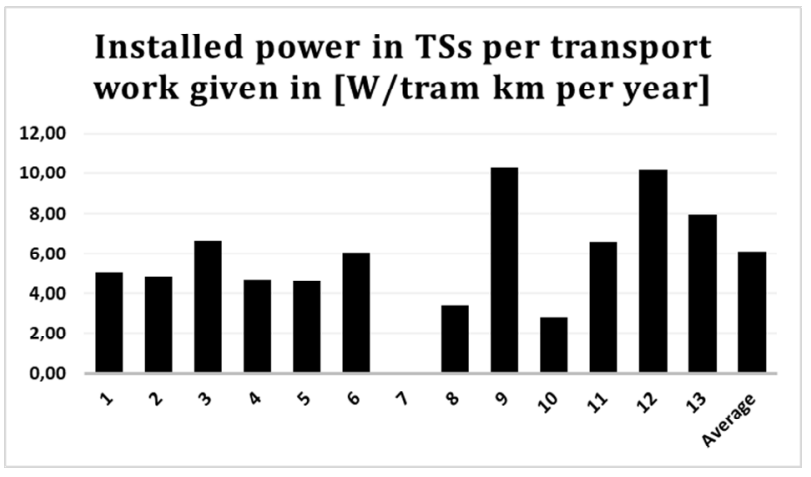

Fig. 23. The value of installed power [W] in TSs per one-year transport work of trams [in tram $\mathrm{km}$ ] in each tram system in Poland and the averaged value for all tram systems.

- in many tram systems, the lengths of a cable network are larger than those of a catenary. Fig. 20). This is a consequence of application of central power supply systems and multiple unit traction substations. The ratio indexes of supply cable lengths to the length of a catenary (Fig. 20) and return cables to the length of a rail network (Fig. 21) provide an overview on the extent of the area of substation supply, but also allow for assessment of power and energy losses and danger of stray currents at known values of load;

- power installed in traction substations per one $\mathrm{km}$ of a line (Fig. 8) and the ratio of power installed in traction substations to average annual number of wagons being operated (Fig. 22) constitute an indicator of use of supplying devices. Depending on a system, power installed in a supply system per an operated tram-train ranges from 187 to $776 \mathrm{~kW}$ during a year, while installed power per train-km per year ranges from 2.8 to $10.3 \mathrm{~kW}$ (Fig. 23). The lower the powers are, the greater is the use of power installed in substations for execution of transport tasks. A unitary power recalculated to the average number of cars in peak hours (including heating and auxiliaries) defines the capacities of a power supply system or - with known average power of vehicles - a limit capacity of a power supply system.

The last indicator should be additionally recalculated for each substation separately. 


\section{Conclusions}

1. Introduction of modern rolling stock poses challenge for the existing electric power infrastructure of urban traction, which is present in the majority of large cities (except for Białystok, Kielce, Radom, Zielona Góra and Opole) (Fig. 1).

2. Sustainable development of major urban centres requires efficient ecological urban transport, i.e. electric transport [8]. However, one should not forget about the fact that Poland has practically no own resources of liquid fuels. Therefore, the strategic role of electric traction cannot be omitted [2].

3. In order to achieve the required effects of operation of electrified urban traction systems, especially in terms of energy savings, one should thoroughly analyse the operational conditions of the existing power supply systems. In some cases technical infrastructure solutions for tram networks existing in Poland are as old as over 100 years, and even after further modernisation, they are still not suitable for supply of rolling stock with a higher power and energy recuperation [1,3]. This implies the need for a detailed analysis of operational conditions of traction electric power systems due to specific requirements of these vehicles. In most cases, it will be necessary to modernise particular sections of power supply and of substations in order to both provide reliability of power supply system operation and achieve an appropriate level of RAMS (Reliability, Availability, Maintainability and Safety) for the target share of rolling stock with recuperation; while on the other hand, increase in effectiveness of the use of regenerative braking and decrease in energy consumption.

4. Analyses conducted for power supply systems of many traction substations [7] proved that at even with considerable low expenditures on the modernised power supply systems one may obtain quick results: an average estimated return on investment amounted to several years of energy savings and, as a result, reduction of $\mathrm{CO}_{2}$ emission. Furthermore, due to modernisation investments, it is possible to achieve effective power supply of modern rolling stock and improve reliability of power supply by decreasing the probability of disturbances and failures. The conducted research [7] includes the following modifications to the existing power supply system in terms of increase of effectiveness of regenerative braking:

- cross-connection via a non-polarised high speed breaker (HSB) (2-point power supply within a traction substation);

- a longitudinal connection - permanent, without a HSB (2-point power supply within a traction substation);

- longitudinal connection - permanent, without a HSB (2-side power supply) between 2 traction substations;

- insulator displacement;

- displacement of a return feeder connection;

- displacement of a supply feeder connection;

- supply feeder extension;

- installation of an energy storage device in a tram;

- installation of an energy storage device in a traction substation;
- installation of an energy storage device outside TS, for instance at the end of supply section.

5. The projects related to electromobility pose challenge, but at the same time constitute an opportunity for development of public electric transport in Poland. Due to a still limited extent of electric autonomous vehicles and the need of frequent charging of energy storage devices, a urban traction network will dominate within the areas of its use, and within the area where a trolleybus system is operated, it will provide an opportunity for hybrid vehicles, namely autonomous and catenary supplied - to broaden the area of their use by charging during a run, and next operating on the sections without a catenary.

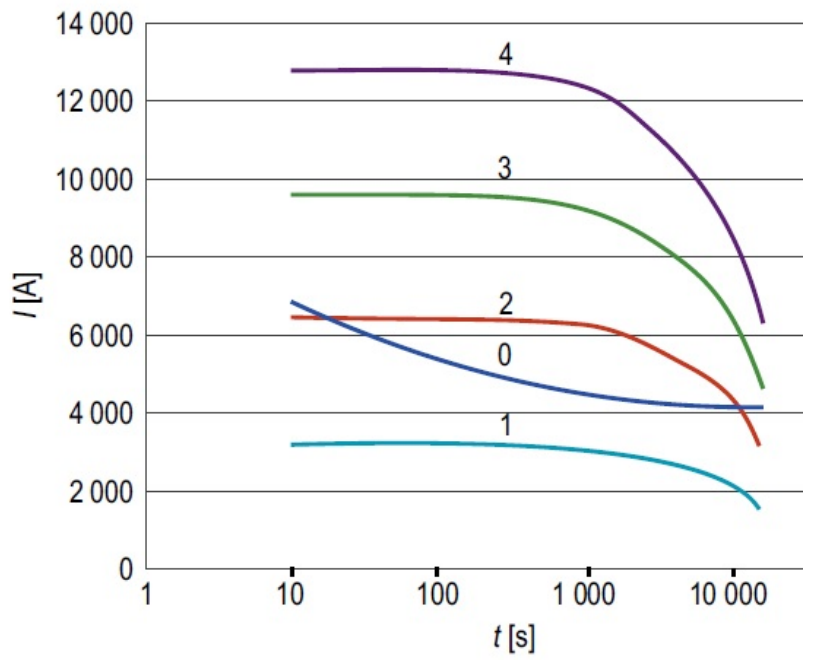

Fig. 24. Results of simulation of a TS current $I$ (curve 0 ) and curves of load current capacity of a TS with 1,2, 3 and 4 rectifiers with 1600 A rated current and V IEC class of overload capacity.

On the other hand, considerable power reserve in traction substations under conditions of normal load (typically in a TS 1 rectifier unit with a rated power of $800-1000 \mathrm{~kW}$ could be switched-off and kept as a cold reserve - Fig. 24) and no loads during night-time (installed power in tram systems is above $500 \mathrm{MW}$ ). This amount of installed power justifies examining the possible use of traction substations (or certain points of a traction catenary) as an energy source for supply of fast charging points (1 rectifier set could supply up to 4 points with $200 \mathrm{~kW}$ power for electric busses) or even creating smart-grids.

\section{References}

1. S. Abe, H. Fuimori and T. Ito, DC feeding system suitable for rolling stocks with regenerative braking system utilizing thyristor rectifier, Proceeding of Fifth European Conference on Power Electronics and Applications, 1993 IET, Brighton, UK, 168-173 (1993)

2. G. Bajno, Influence of energy regeneration on the power supply of the Filtrowa and Annopol traction substations in Warsaw Trams [Wpływ rekuperacji energii na układ zasilający podstacji trakcyjnej 
„Filtrowa” i „Annopol” w Tramwajach Warszawskich], Proceeding of 11th International Conference “Modern Electric Traction” MET'2013, Warsaw, Poland,(2013) [in Polish]

3. J. Czucha, K. Karwowski, M. Mizan and P. Pazdro, Efficiency of recuperative electrodynamics braking energy in urban transport [Efektywność odzysku energii hamowania elektrodynamicznego $w$ komunikacji miejskiej], Przegląd Elektrotechnicz, 10(80), 1016-1019 (2004) [in Polish]

4. M. Bartłomiejczyk, Practical application of in motion charging: Trolleybuses service on bus lines, Proceeding of 18th International Scientific Conference Electric on Power Engineering (EPE), Kouty nad Desnou, Czech Republic, 1-6 (2017)

5. M. Bartosik, W. Kamrat, M. Kaźmierkowski, W. Lewandowski, M. Pawlik, T. Peryt, T. Skoczkowski, A. Strupczewski and A. Szeląg, Power sources and safety of electrical energy distribution in Poland [Bezpieczeństwo elektroenergetyczne dla pokoleń], Przegląd Elektrotechniczny, 8(92), 268-282 (2016) [in Polish]

6. A. Majchrzycki and K. Tuliński, Energy regeneration - a key for optimalization of finances or additional technical problems [Rekuperacja energii - klucz do optymalizacji kosztów czy dodatkowe problemy techniczne], Electric traction. Scientific researches. Monography of the $2^{\text {nd }}$ congress of Polish electric power industry [Trakcja elektryczna. Prace Naukowe. Monografia II Kongresu Elektryki
Polskie], edited by A. Szeląg, (COSIW, SEP, Warsaw 2016) [in Polish]

7. Ch. Schreyer, Ch. Schneider, M. Maibach, W. Rothengatter, C. Doll and D. Schmedding, External costs of transport. Update study. Final Report, (Zurich/Karlsruhe 2004)

8. A. Szeląg, Improvement of the electrical effectiveness of railway transport [Zwiększanie efektywności energetycznej transportu szynowego], Railway Transport Tecgnology [Technika Transportu Szynowego], 12, (2008) [in Polish]

9. A. Szeląg, T. Maciołek, Z. Drążek and M. Patoka, Aspects of effectiveness and energy saving in the process of modernization of power supply of tram traction [Aspekty efektywności i energooszczędności $w$ procesie modernizacji układow zasilania trakcji tramwajowej],Pojazdy Szynowe, 3, 34-42 (2011) [in Polish]

10. A. Szeląg, Z. Drążek, T. Maciołek and M. Patoka, Study of power supply of tram traction in Warsaw Trams PLC [Studium układu zasilania trakcji tramwajowej Tramwajów Warszawskich sp. z o.o.], Research of Electric Traction Division of Warsaw University of Technology on the order of Warsaw Trams PLC [Praca Zakładu Trakcji Elektrycznej PW na zlecenie Tramwajów Warszawskich sp. z o.o.], Warsaw (2010-2011) [in Polish]

11. M. Yasunami, Transportation Systems: Their Technical Trends, Hitachi Review, 4(40), (1991) 